\title{
The Use of L1 in the Foreign Language Classroom
}

\section{El uso de la lengua materna en el salón de inglés como lengua extranjera}

\author{
Yi-chun Pan \\ Lecturer, Center for General Education \\ National Pingtung Institute of Commerce, Pingtung, Taiwan \\ Tamkang University, Tamsui, Taiwan \\ E-mail: pan_yichun@yahoo.com \\ Yi-ching Pan \\ Lecturer, Center for General Education \\ National Pingtung Institute of Commerce, Pingtung, Taiwan \\ E-mail: huangpan63@yahoo.com
}

\begin{abstract}
L1 use is a common occurrence in foreign language teaching contexts despite the fact that it often receives criticism for its interference with target language $(T L)$ acquisition. While foreign language teachers should maximize their use of the $T L$, there is indeed a place for the teacher to use the students' $L 1$ in their pedagogy. In this paper, an argument derived from theoretical perspectives and empirical research within existing literature supporting the appropriate use of $L 1$ in foreign language classrooms is presented. The argument addresses three key issues-rationales for L1 use, positive effects L1 has on both foreign language learning and instruction, and ways that L1 assists instructors on foreign languages.
\end{abstract}

Key words: $L 1$ use, $T L$, foreign language classrooms

\section{Resumen}

El uso de la lengua materna es una ocurrencia común en los contextos de la enseñanza de la lengua extranjera, a pesar de que a veces reciba críticas por su interferencia en la adquisición de la Lengua meta. Mientras que los docentes deben maximizar el uso de la Lengua meta, sin duda, hay espacios para que el profesor utilice la lengua materna de los estudiantes en su pedagogía. En este trabajo se presenta un argumento basado en las perspectivas teóricas y la investigación empírica dentro de la literatura existente, apoyando el uso apropiado de la Lengua materna en el salón de inglés como lengua extranjera. El argumento se centra en tres cuestiones fundamentales-racionales para el uso de la lengua materna: Los efectos positivos que la lengua materna tiene tanto en el aprendizaje y la instrucción de una lengua extranjera, como en las formas en las que la lengua materna ayuda a los docentes de idiomas extranjeros.

Palabras clave: Uso de la lengua materna, lengua meta, salón de inglés como lengua extranjera

Received 12-11-2009 / Accepted 09-09-2010

Colomb. Appl. Linguist. J.

Vol. $12 \cdot$ Number 2 - ISSN 0123-4641 • Bogotá, Colombia. Pages 87-96 


\section{Introduction}

Although exclusive or maximal use of the target language (TL) has been promoted in foreign language (FL) education (Savignon, 1983; Widdowson, 1978), classroom-based research has disclosed that teachers alternate between using the mother tongue (L1) and TL in FL classrooms (Chang, 2009; Ferguson, 2003; Macaro, 2001; Tien, 2004; Turnbull E Arnett, 2002). Due to the fact that teacher code switching is evident in FL contexts, many researchers (Atkinson, 1987; Auerbach, 1993; Cook, 2001; Harbord, 1992; Johnson E Lee, 1987; Kang, 2008; Rolin-Ianziti \& Brownlie, 2002; Storch \& Wigglesworth, 2003; Swain \& Lapkin, 2000; Turnbull, 2001; Van Lier, 1995; Weschler, 1997) have re-examined the TL-only position. In general terms, these researchers warn against the excessive use of L1, but they do advocate using it judiciously in occasions such as eliciting language, assessing comprehension, giving instructions, and explaining grammar. The principled use of L1 in conjunction with TL has been proposed for a variety of pedagogical reasons: to provide scaffolding for tasks (Anton \& Dicamilla, 1998), to promote the transition from L1 to TL use (Shamash, 1990), to improve negotiations (Swain E Lapkin, 2000), and to enhance TL comprehension (Turnbull, 2001).

Several studies have demonstrated the benefits of using L1 to learn a TL. For example, Villamil and de Guerrero (1996) analyzed the discourse of Spanish-speaking university students while they engaged in peer revision of their TL (English) writing. Their data demonstrates that "the L1 was an essential tool for making meaning of text, retrieving language from memory, exploring and expanding content, guiding their action through the task, and maintaining dialogue" (p. 60). Similarly, Swain and Lapkin (2000), in their examination of the L1 uses by 22 pairs of Grade 8 French immersion students as they completed dictogloss and jigsaw tasks, found that if the students had not used L1 as a means of negotiation and communication, the tasks may not have been accomplished as effectively, or perhaps they might not have been accomplished at all. Furthermore, Hsieh (2000) discovered that translation, one way of using L1, improved her college students' ability to read English in terms of reading comprehension, reading strategies, vocabulary learning, and cultural background knowledge.

Despite the fact that the empirical benefits of using L1 are readily apparent, the governments of several Asian countries in which English is a foreign language (e.g.,Korea and Taiwan) suggest that the use of L1 be kept to an absolute minimum (Lu et al., 2004). These official guidelines have resulted in guilt on the part of English teachers who use L1. However, there is no need for these teachers to feel guilty. If L1 is utilized well and presented communicatively, it can be a facilitative tool that will improve the language proficiency of students. This paper argues for the appropriate use of L1 in foreign language learning environments by drawing on theoretical perspectives and empirical work in the existing literature. Three key issues are addressed: the rationales for the use of $\mathrm{L} 1$, the positive effects of L1 on foreign language learning and teaching, and the ways in which L1 can assist foreign language teachers.

\section{The Rationales}

Using L1 in foreign language classrooms is discouraged by advocates of the TL-only position (Chaudron, 1988; Krashen, 1982; Macdonald, 1993). These advocates contend that students must be exposed to a significant amount of TL input if they want to develop better TL proficiency, so using L1 in the classroom deprives students of that valuable input. However, maximizing 
the TL use does not and should not mean that it is harmful for the teacher to use the L1 (Turnbull, 2001). Macaro (2005) argues that the avoidance of L1 results in increased usage of input modification (e.g. repetition, speaking more slowly, substituting basic words for more complex ones, simplifying syntax, etc.). This in turn might bring about negative effects in any interaction, making the discourse less realistic, reducing the lexical diversity, and eliminating exposure to complex syntax. According to Macaro, input modification might facilitate communication, but it does not assist students in their acquisition of complex linguistic knowledge (e.g. vocabulary, phrases, and grammar). Macaro presented the following example: If teachers avoided code switching to L1 to introduce a phrase such as 'raised in the gutter' and instead substituted a paraphrased version (brought up badly by poor parents), students, especially those with lower proficiency levels, might be deprived of learning the original phrase. Although students might better comprehend the teacher's spoken remarks via modified input, they do not learn the new aspect of TL. Similarly, Gunn (2003) argues for the use of L1 for adult students, particularly those with lower proficiency, because if the L1 is not used at all, tasks and activities must be kept simple to ensure that the instructions are understandable. These juvenile tasks and activities might result in teachers treating adult learners like children rather than intelligent and sophisticated people.

Additionally, some scholars feel that switching from TL to L1 can be an effective strategy for improving student proficiency in TL if L1 is deliberately utilized in classrooms. These opponents of the TL-only practice argue against it from a number of language learning perspectives. For example, Anton and DiCamilla (1998) found that L1 can serve as a very useful cognitive tool, providing scaffolding for students in their effort to achieve learning tasks. Likewise, Brooks and Donato (1994) indicate that the L1 enables students to negotiate meaning and communicate successfully in the TL. These scholars argue that the avoidance of L1 use denies TL learners a valuable educational tool. Their argument is based particularly on the interactionist learning theory (Ellis, 1994), which suggests that input alone is insufficient for achieving language acquisition. To allow input to readily become knowledge, there must be interaction between TL learners and other speakers. This interaction will elicit the negotiation of the meaning of the input (Long, 1996) and the production of the output (Swain, 1995). Many TL learners regard L1 as an essential tool in the learning process because they interact with peers and teachers (Villamil $\mathcal{E}$ de Guerrero, 1996), and using L1 often assists TL learners in their creation of a social and cognitive space within which effective work can be done toward improving their learning (Anton E DiCamilla, 1988). Moreover, the teacher's use of L1 provides an enhanced form of input that is more salient for the learners, more easily processed, and consequently promotes their learning (Van Lier, 1995).

Furthermore, the use of L1 may assist stu-dents in reducing affective barriers and increasing their confidence in their ability to successfully comprehend the TL (Atkinson, 1987; Auerbach, 1993; Cook, 2001; Harbord, 1992; Johnson \& Lee, 1987; Kang, 2008; Kern, 1989). For example, Seng and Hashim (2006) indicate that lower proficiency students usually have difficulty expressing or verbalizing their thoughts with confidence and accuracy, so they should be allowed to fall back on L1 to understand the TL. In fact, Liao (2006) has observed that when the TL is the only medium allowed in discussions, students remain silent due to their nervousness or lack of English competence. In contrast, when both L1 and TL are allowed as media for discussions, 
there is more participation and meaningful communication is sustained longer. Therefore, the use of L1 results in an increased willingness by students to communicate verbally and express their ideas (Atkinson, 1987; Auerbach, 1993; Cook, 2001).

\section{The Positive Effects of L1}

Some foreign language teachers believe that the best way for students to develop native-like language proficiency is to think in that language. In order to avoid and eliminate the errors caused by L1 interferences, students are encouraged to suppress the use of L1 as a means of learning the TL. However, second language acquisition research (Dulay E Burt, 1973; Johnson E Newport, 1994) has revealed that the difficulties and errors of foreign language learning cannot be completely attributed to interference by the learners' first language. In an investigation analyzing the sources of errors among nativeSpanish-speaking children learning English, Dulay and Burt (1973) found that only 3\% of errors came from L1 interferences and 85\% of errors were developmental in nature. These findings imply that the fear of using L1 in foreign language classrooms, which results in negative transfer, should be reduced.

In addition to research that demonstrates that L1 should not be considered a hindrance to successful learning (Dulay \& Burt, 1973; Johnson $\varepsilon$ Newport, 1994), some scholars have brought L1's positive effects on both foreign language teaching and learning to light (Anton E Dicamilla, 1998; Cipriani, 2001; Bergsleighner, 2002; Storch \& Willesworth, 2003; Greggio \& Gil, 2007; Kang 2008). For example, Anton and Dicamilla's study (1998), in which five pairs of Spanish-speaking EFL adult learners conducted English writing tasks, revealed several of the many functions that L1 can serve. These functions include the fostering and maintenance of interest in the task in addition to the development of strategies and approaches for making difficult tasks more manageable. Anton and Dicamilla (1998) believe that the use of L1 is beneficial for language learning because it both helps in the process and completion of the task and creates a social and cognitive space in which students will be able to provide each other with assistance throughout the duration of the task. Moreover, thinking in L1 results in the production of more elaborate content. Lally's research (2000) revealed that students who prepared a writing task in L1 received higher scores for organization. In another study conducted by Cohen and Brooks-Carson (2001), the group reported that they almost always had more ideas and a greater amount of clear thinking in L1.

In an investigation of oral participation strategies in a beginner group, Cipriani (2001) observed that L1 was one of the strategies that elicited oral participation between teachers and students. Her data also revealed that the teacher utilized L1 to explain vocabulary, to communicate tasks, and to encourage students to speak in English. Furthermore, the students' use of L1 as an oral strategy enabled them to continue communicating in English. In another example of L1 used as an oral communication strategy, Bergsleighner's (2002) examination of grammar and interaction in a pre-intermediate EFL classroom revealed that L1 was utilized by students to achieve better self-expression in interactions with the teacher and to negotiate form and meaning. She also discovered that L1 was adopted by the teacher to effectively facilitate student comprehension of grammar topics. Furthermore, Storch and Wigglesworth (2003) analyzed data collected from twelve pairs of university ESL students as they engaged in a short joint composition task. They reported that the use of L1 enabled in-depth discussion of the 
prompt and the structure of the composition, thus allowing the students to complete the task more easily. Moreover, L1 use assisted these students in defining unknown words more directly and successfully.

In yet another example, Greggio and Gil (2007) audio-recorded twelve class sessions of Portuguese-speaking beginner EFL learners. They determined that the teacher utilized L1 as an effective teaching strategy for the explanation of grammar and the offering of feedback. Students used L1 as a viable learning strategy to both clarify their understanding of lesson content and as a means of participating in class discussion. Based on these results, Greggio and Gil offer the suggestion that L1 may play an important role in the facilitation of interaction between classroom participants as well as foreign language learning. Liao's (2006) investigation into the role L1 plays for Taiwanese college students learning English identifies three strategic functions in the students' use of L1. First, students use L1 as a memory strategy to improve their ability to memorize words, idioms, grammar, and sentence structures. Second, L1 is used as an affective strategy for reducing learning anxiety and increasing their motivation to learn English. Third, students utilize L1 as a social strategy to assist them in asking questions or cooperating with others, and this, in turn, promotes their learning outcomes. Building upon these three strategic functions, Kang's (2008) case study of a Korean EFL teacher, showed that the teacher used L1 for pedagogical reasons such as explaining grammar, organizing tasks, disciplining students, and implementing tests. Furthermore, the students in this study exhibited a positive response to their teacher's L1 use in that it improved their understanding of lessons and maintained their interest in learning English.

L1 use may facilitate TL classroom activities due to the fact that the use of $\mathrm{L} 1$ provides a beneficial scaffolding that assists learners in understanding tasks and solving specific problems. While many scholars (Cook, 2001; Harbord, 1992; Turnbull, 2001; Turnbull \& Arnett, 2002) agree that L1 can be a valuable resource in foreign language classrooms, they caution that educators should not rely upon it to any significant degree (Wells, 1999).

\section{Principled L1 Use}

How can the L1 be better integrated into teaching? Cook (2001) has proposed four guidelines that teachers should take into consideration. The first factor is efficiency. For example, L1 may help present the meanings of abstract and complicated vocabulary items in a less time consuming but more effective manner. The second factor is learning. Learning subjunctive moods could be facilitated by using L1 explanations. The third factor is naturalness. It may be easier for teachers to create an environment of rapport by showing concern for their students in L1 than it would be in the TL. It is a possibility that the use of both languages meet students' needs in the everyday world outside of the classroom. The fourth factor is external relevance. Knowing how to present a product in both L1 and TL might help students be successful in their careers. These four factors serve as guidelines for helping teachers incorporate judicious L1 use that will facilitate students' foreign language learning in ways that the use of the TL most likely never could.

The existing literature on teacher code switching groups appropriate and effective code switching into three major categories (Chang, 2009; Edstrom, 2006; Ferguson, 2003; Macaro, 2001; Tien, 2004; Turnbull \& Arnett, 2002). The first category is code switching for curriculum access. Examples of this include conveying meaning of words or sentences, 
explaining grammar, and displaying cultural issues. Category two is switching codes for classroom management discourse, examples of which are organizing tasks, disciplining, and praising students. The third and final grouping is that of code switching for interpersonal relations. Examples in this category include the humanization of the affective climate of the classroom, such as chatting with students and telling jokes.

In terms of conveying the meaning of new words, the students' previous L1 learning experience may be beneficial to them because it can be exploited to increase their understanding of the TL (Prince, 1996). For example, if students are aware of the impressionist style of painting, it will be much more effective for their teacher to use L1 to convey the meaning of impressionism than to describe it in the TL. According to Atkinson (1993), learning a language is a difficult and often frustrating process for many students, particularly at low levels. TL-only instruction can be frustrating, but the occasional use of L1 can have a powerful, positive effect. In line with Atkinson, Lee (2000) asserts that when addressing vocabulary difficulties, students use L1 to confirm, to reason through, or to guess unfamiliar TL words. It is possible that the students' ability to utilize the L1 input enabled them to complete their reading tasks more successfully. This argument may be extended to include the fact that teachers can facilitate student learning by making the L1 available to them. Lee, Seng and Hashim (2006) believe that the use of L1 to instruct words and patterns increases students' awareness regarding the differences between L1 and TL, thus eliminating negative transfer. However, Harbord (1992) cautions teachers to restrict the use of L1 explanations to abstract, complicated words or sentences that would otherwise confuse students if explained in the TL. If a word or sentence is simple enough, it is worthwhile to take the time to define or explain it in the TL. When a teacher continues using L1 to explain simple vocabulary or sentences, they are using too much L1. In Harbord's opinion, students still require abundant exposure to TL unless instructions communicated in TL lead to miscomprehension and frustration.

As for grammar explanation, grammatical competence is a critical element of successful language learning (Canale E Swain, 1980). According to Cook (1997), even advanced TL users are less efficient at absorbing linguistic information from the TL than they are from the L1. Cook (2001) argues that L1 should be used for grammar instruction because lowerproficiency students possess little TL linguistic information, so L1 provides a shortcut for constructing associations between L1 and TL knowledge in students' minds. Likewise, Husain (1995) claims that the use of L1 provides foreign language learners with a quick and efficient method for analyzing and comprehending the structure of the target language. Additionally, a systematic contrastive analysis between L1 and TL can help raise students' awareness of the major differences between the two languages and eliminate awkward instances of literal word-byword translation in students' writing. Moreover, Atkinson (1987) proposes that teachers should explain or demonstrate grammatical rules in L1 and then develop TL dialogues that integrate these rules, thus helping students to reinforce them. Alternatively, Chellappan (1991) suggests that teachers use translation exercises after instructing grammar rules. A contrastive analysis between two languages helps students not only to grasp the main grammatical characteristics of TL but also to eliminate negative interferences from L1.

In foreign language classrooms teaching about culture is an important objective that should be integrated into language study, not 
separated from it. Many aspects of the target culture can certainly be highlighted in the TL through visual images such as pictures and film clips. However, Edstrom (2006) has suggested the use of L1 if students make comments that reveal stereotypical understandings or inaccurate comprehension. For example, some Asian students have the misconception that Americans are not as respectful to their parents as Asians are, because they send their parents to nursing homes when they are old. In a situation like this, helping students interpret other cultures in non-stereotypical ways is more important than concerns about students' TL acquisition process. This goal is not always possible to achieve through the TL, given students' proficiency levels and awareness of cultural matters. Through illustration in L1, students will be more likely to understand the reasons why Americans send their elderly parents to nursing homes and consequently develop non-judgmental attitudes toward cultures in other countries.

Considering organizing tasks, TL instruction is certainly recommended for simple tasks due to the fact that explaining an activity in the TL is genuine communication. However, some scholars (Willis, 1981; Weschler, 1997) feel that using L1 to give instructions for complicated tasks, particularly to lower-level students, is a justified use. In the opinions of these researchers, a little L1 can go a long way towards making an enjoyable task possible in these situations. Another alternative is to give the instructions in the TL and then ask students to repeat them in the L1 in order to ensure that everyone fully understands what to do.

As for managing student behavior, one of the many responsibilities of teachers is to create a non-interfering learning environment. When a student misbehaves, Franklin (1990) reported that $45 \%$ of teachers in his study preferred the L1 for discipline for two reasons: for efficiency of comprehension and to show that the threat is real rather than imagined. And in terms of praising students, Edstrom (2006) states that it is important for teachers to establish rapport and solidarity with students. When students do a good job, Edstrom recommends using L1 to tell them how well they have done because the use of L1 may reinforce the fact that the praise is real. Furthermore, Edstrom claims that positive affective consequences are not peripheral, especially for students who enter the classroom in fear or with resent. Concern about communicating respect and creating a positive environment overrides the desire to maximize TL use. As for facilitating the student-teacher relationship, lowering student anxiety and achieving a good teacher-student rapport are quite desirable aims that should be actively encouraged. Harbord (1992) suggests that teachers chat in L1 before class starts and tell jokes in L1 to reduce student anxiety.

\section{Conclusion}

The use of L1 in FL classrooms is justified, but none of its supporters endorse its unlimited use. Many advocates (Atkinson, 1987; Cook 2001; Swain \& Lapkin, 2000; Wells, 1999) warn against excessive L1 use, instead proposing that it be used optimally. To these scholars, L1 should only be used to help construct knowledge in the target language, facilitate interpersonal interactions, and increase efficiency. In no way should L1 be accorded the same status as TL in the classroom. FL teachers must assist their students to take advantage of their existing L1 to facilitate their learning of L2. Research studies have revealed that L1 is not only an efficient learning tool but also a useful teaching method if pedagogical activities are well designed. Students use L1 to facilitate their process of comprehension and to reduce any insecurities that may arise from their limited language proficiency. Teachers use 
L1 to consolidate knowledge that students have learned about the foreign language, such as its vocabulary, sentence structures, and cultural aspects. One must also keep in mind that an appropriate quantity of L1 use by teachers cannot be defined universally because it depends on students' proficiency levels and teaching purposes. L1 may be used from introductory to lower-intermediate levels on a decreasing scale. Lower-level students, especially those who are mature, can benefit from the explanation of grammar usage and instructions. In conclusion, students' L1 is an overwhelmingly powerful tool that should neither be denied nor abandoned in foreign language classrooms. It is critical for teachers to realize the effectiveness of students' L1 and attempt to use it positively. This is a concept that no serious foreign language teacher should ignore.

\section{References}

Anton, M., \& DiCamilla, F. (1998). Socio-cognitive functions of $\mathrm{L} 1$ collaborative interaction in the $\mathrm{L} 2$ classroom. Canadian Modern Language Review, 54(3), 314-342.

Atkinson, D. (1987). The mother tongue in the classroom: A neglected resource? ELT Journal, 41(4), 241-247.

Atkinson, D. (1993). Teaching in the target language: A problem in the current orthodoxy. Language Learning Journal, 8(1), 2-5.

Auerbach, E. (1993). Reexamining English only in the ESL classroom. TESOL Quarterly, 27(1), 9-32.

Bergsleighner, J. M. (2002). Grammar and interaction in the EFL classroom: A sociocultural study. Dissertation, Universidade Federal de Santa Catarina, Florianópolis.

Brooks, F., \& Donato, R. (1994). Vygotskian approaches to understanding foreign language learner discourse during communicative tasks. Hispania, 77, 262-274.

Canale, M., \& Swain, M. (1980). Theoretical bases of communicative approaches to second language teaching and testing. Applied Linguistics, 1, 1-47.

Chang, C.-Y. (2009). Teacher's use of students' $L 1$ in an EFL classroom. Unpublished master's thesis, National Cheung Kang University, Taiwan.
Chaudron, C. (1988). Second language research: Research on teaching and learning. Cambridge, England: Cambridge University Press.

Chellappan, K. (1991). The role of translation in learning English as a second language. International Journal of Translation, 3, 61-72.

Cipriani, F. (2001). Oral participation strategies in the foreign language classrooms: an ethnographic account. Dissertation, Universidade Federal de Santa Catarina, Florianópolis.

Cohen, A.D., \& Brooks-Carson, A. (2001). Research on direct versus translated writing: Students' strategies and their results. The Modern Language Journal, 85(2), 169-188.

Cook, V. J. (1997). The consequences of bilingualism for cognitive processing. In A. de Groot \& J. F. Kroll (Eds.), Tutorials in bilingualism: Psycholinguistic perspectives (pp. 279-299) Hillsdale, NJ: Lawrence Erlbaum.

Cook, V. (2001). Using the first language in the classroom. The Canadian Modern Language Review, 57(3), 402423.

Dulay, H., \& Burt, M. (1973). Should we teach children syntax? Language Learning, 23, 245-258.

Edstrom, A. (2006). L1 use in the L2 classroom: One teacher's self-evaluation. The Canadian Modern Language Review, 63(2), 275-292.

Ellis, R. (1994). The study of second language acquisition. Oxford, England: Oxford University Press.

Ferguson, G. (2003). Classroom code-switching in post-colonial contexts: Functions, attitudes and policies. AlLA Review, 16, 38-51.

Franklin, C. E. M. (1990). Teaching in the target language. Language Learning Journal, 2, 20-24.

Greggio, S., Gil, G. (2007). Teacher's and learner's use of code switching in the English as a foreign language classroom: A qualitative study. Linguagem \& Ensino, 10(2), 371-393.

Gunn, M. (2003). Opportunity for literacy? Pre-literate learners in the AMEP. In G. Wiglesworth (Ed.), The kaleidoscope of adult second language learning: Learner, teacher and researcher perspectives (pp. 251-272.). Sydney: NCELTR.

Harbord, J. (1992). The use of the mother tongue in the classroom. ELT Journal, 46, 350-355.

Hsieh, L. T. (2000). The effects of translation on English vocabulary and reading learning. Selected papers 
from the Proceedings of the Ninth International Symposium on English Teaching in the Republic of China. Taipei: The Crane Publishing Co.

Husain, K. (1995). Assessing the role of translation as a learning strategy in ESL. International Journal of Translation, 1(2): 59-84.

Johnson, R. K., \& Lee, P. M. (1987). Modes of instruction: Teaching strategies and student responses. In R. Lord and H. N. L. Cheng (Eds.), Language education in Hong Kong (pp. 99-121). Hong Kong: The Chinese University Press.

Johnson, J. S., \& Newport, E. L. (1994).Critical period effects in second language learning: the influence of maturational state on the acquisition of English as a second language. In D. Brown, H. \& S. Gonzo (Eds.), Readings on Second La guage Acquisition (pp. 75-115). Upper Saddle River, NJ: Prentice Hall Regents.

Kang, D.-M. (2008). The classroom language use of a Korean elementary school EFL teaching: Another look at TETE. System, 36, 214-226.

Kern, R. G. (1989). Second language reading strategy instruction: Its effect on comprehension and word inference ability. Modern Language Journal, 73(2), 135-149.

Krashen, S. (1982). Principles and practice in second language acquisition. New York: Pergamon Press.

Lally, C. G. (2000). First language influences in second language composition: The effect of pre-writing. Foreign Language Annals, 33(4), 428-432.

Lee, C. D. (2000). Signifying in the zone of proximal development. In C. D. Lee and P. Smagorinsky (Eds.), Vygotskian perspectives on literacy research: Constructing meaning through collaborative inquiry (pp. 191-225). Cambridge: Cambridge University Press.

Liao, P. (2006). EFL learners' beliefs about and strategy use of translation in English learning. RELC, 37(2), 191-215.

Long, M. (1996). The role of the linguistic environment in second language acquisition. In W. Ritchie \& T. Bhatia (Eds.), Handbook of second language acquisition (pp. 413-468). San Diego, CA: Academic.

Lu, D., Ahn, G.-S., Bake, K.-S., \& Han, N.-O. (2004). South Korean high school English teachers' codeswitching: Questions and challenges in the drive for maximal use of English in teaching. TESOL Quarterly 38(4), 605-638.

Macaro, E. (2001). Analyzing student teacher's code switching in the foreign language classrooms:
Theories and decision making. The Modern Language Journal, 85, 531-548.

Macaro, E. (2005). Codeswitching in the L2 classroom: A communication and learning strategy. In E. Llurda (Ed.), Non-native language teachers. Perceptions, challenges and contributions to the profession (pp. 63-84). New York: Springer.

Macdonald, C. (1993). Using the target language. Cheltenham, England: Mary Glasgow.

Prince, P. (1996). Second language vocabulary learning: The role of context versus translation as a function of proficiency. The Modern Language Journal, 80, 478-493.

Rolin-lanziti, J., \& Brownlie, S. (2002). Teacher use of learners' native language in the foreign language classroom. The Canadian Modern Language Review, 58(3), 402-426.

Savignon, S. (1983). Communicative competence: Theory and classroom practice. Reading, MA: Addison-Wesley.

Seng, G. H., \& Hashim F. (2006). Use of L1 in L2 reading comprehension among tertiary ESL learners. Reading in a Foreign Language, 18(1).

Shamash, Y. (1990). Learning in translation: Beyond language experience in ESL. Voices, 2(2), 71-75.

Storch, N., \& Wigglesworth, G. (2003). Is there a role for the use of the L1 in an L2 setting? TESOL Quarterly, 37(4), 760-770.

Swain, M. (1995). Three functions of output in second language learning. In G. Cook \& B. Seidlhofer (Eds.) Principles and practice in applied linguistics: Studies in honor of H. G. Widdowson (pp. 125-144). Oxford, England: Oxford University Press.

Swain, M., \& Lapkin, S. (2000). Task-based second language learning: The uses of the first language. Language Teaching Research, 4, 251-274.

Tien, C.-Y. (2004). Code-switching in two freshman English classrooms in a university in southern Taiwan. Unpublished doctoral dissertation, University of Leicester.

Turnbull, M. (2001). There is a role for the $L 1$ in second and foreign teaching, but .... The Canadian Modern Language Review, 57(4), 531-538.

Turnbull, M., \& Arnett, K. (2002). Teachers' uses of the target and first languages in second and foreign language classrooms. Annual Review of Applied Linguistics, 22, 204-218. 
Van Lier, L. (1995). The use of the L1 in L2 classes. Babylonia, 2, 37-43.

Villamil, O., \& de Guerrero, M. (1996). Peer revision in the L2 classroom: Socio-cognitive activities, mediating strategies, and aspects of social behavior. Journal of Second Language Writing, 5, 51-75.

Wells, G. (1999). Using L1 to master L1: A response to Antom and Dicamilla's "Socio-cognitive functions of L1 collaborative interaction in the L2 classroom." The Modern Language Journal, 83(2), 248-254.
Weschler, R. (1997). Uses of Japanese (L1) in the English classroom: Introducing the functionaltranslation method. The Internet TESL Journal, 3(11). On-line. Available at http://iteslj.org/articles/Weschler-usingL1.html

Widdowson, H. G. (1978). Teaching language as communication. Oxford: Oxford University Press.

Willis, J. (1981). Teaching English through English. Essex: Longman. 